\title{
Competency-based Teaching of Shakespeare: How to Master King Lear
}

\author{
Purificación Ribes \\ University of Valencia, Facultad de Filología, Traducción y Comunicación \\ Dpto. Filología Inglesa y Alemana \\ Avda. Blasco Ibáñez, 32, 46010 Valencia, Spain
}

Tel: 34-963-983-004Ｅ-mail: purificacion.ribes@uv.es

Received: November 22, 2011

Accepted: November 28, $2011 \quad$ Published: December 1, 2011

doi:10.5539/ies.v4n5p18

URL: http://dx.doi.org/10.5539/ies.v4n5p18

\begin{abstract}
Shakespeare's hypotext has invited so many hypertextual transformations over the last four hundred years that twenty-first century students deserve the chance of digging into this rich mine of information and dramatic possibilities. The practical approach of a competency-based teaching method offers great advantages over traditional practices in that it devises a series of specific tasks for students to perform. As a result, their linguistic, historical, theatrical and intercultural skills are enhanced to such an extent that they acquire the competence they need to approach other early modern texts in a confident manner. This paper suggests a variety of tasks which can help students achieve this goal in a satisfactory way. Students are offered different textual versions of King Lear for comparison and commentary. They are likewise provided with excerpts from historical documents that cast light on Lear's political and cultural context. Finally, different filmed versions of the play are watched and discussed, paying attention to their choice of setting, costumes, props, music, as well as to the hierarchical relationship between different semiotic systems.
\end{abstract}

Keywords: Competency-based, Teaching, King Lear

\section{Introduction}

The present paper consists of a series of methodological considerations on the teaching of classical literary texts that is followed by practical suggestions on a specific case in point: Shakespeare's King Lear. Its aim is the achievement on the part of students of the necessary competences to read the play with a critical eye and the development of the necessary skills to approach similar plays successfully.

\section{Teaching Classical Texts: Methodological Considerations}

\subsection{Literary Studies and the Development of Critical Thinking}

As E. McGee argues, "liberal arts education leads to the achievement of marketable skills in critical thinking, problem solving, research methods, and the use of the English language" (2002, p.106). Biddy Martin similarly highlights the role played by the teaching of literature in the building of "more vigorous and more critical cultures" (1997, p.7), an aim that is shared by Durant and Fabb when they stress the importance of literary studies for the "development of the student's critical thinking" (1992, p.4).

As we all know from experience, the achievement of this worthy aim entails a careful selection not only of texts for study but also of critical approaches to them. As regards the first aspect, in our view, the prolonged textual and theatrical history of the text chosen for analysis -Shakespeare's King Lear-is clearest proof of its capacity to elicit the student's critical response. The richness of Shakespeare's hypotext as well as the variety of the hypertextual transformations that the Jacobean play has undergone throughout history have been the focus of a wide number of critical approaches which have dealt with different aspects of King Lear.

Traditionally, different critical trends have tended to focus on the play's verbal texture as opposed to its historical context and vice-versa. Similarly, specific critical approaches such as cultural materialism or feminism have tended to concentrate on highly specific - and, at the same time, limited-aspects of the play.

Critical attention to plays in general has tended to be so theoretical that voices have recently been raised in favour of more specific applications of those abstract principles to the teaching of literary texts. This is Rob Pope's view when he recalls that "the moment of 'high theory' (i.e. highly abstract theory) has passed" and adds: "there is now a 
growing concern with theory in practice [...] The emphasis is on what can be done rather than on what it is" (1998, p.42) (Note 1).

We have now reached a point when there seems to exist widespread agreement on the convenience of choosing an eclectic method to approach literary texts -this is for example Leggatt's (2002, p.4), as well as Martin's (1997, p.12) view-, a method whose plurality of approach is, in Pope's words, "flexible yet principled" (1998, p.42), and which identifies the models and methods appropriate to specific tasks. Such a method acknowledges that literary texts are word constructs, and therefore require a detailed analysis of their verbal texture, but, at the same time, realizes that the meaning of texts is context-dependent and varies according to the specific circumstances of production and reception.

\subsection{Analysing the Play's Verbal Texture in (Changeable) Context(s)}

Aware of the complex nature of literary texts, teachers tend to begin by paying attention to their linguistic texture since, in Joseph Candido's words, “once students have done it, they can feel more confident about discussing any other critical concern that may be of interest" (2002, p.51).

Biddy Martin, however, highlights the importance of these "other critical concerns" when he says: "we cannot afford to limit the subject of literature to an objective study of discourse". He only deems appropriate those "critical and pedagogical practices that make students mindful of the tensions, contradictions, ambivalences and pleasures in reading" (1997, p.23). Martin insists that in teaching students the art of critical thinking,

[W] e must show them how to keep questions open and convince them that meaning, agency, and value are not in one place, nor in the author's intentions or unconscious motivations, in the text's context, formal dimensions, content, or unity (or lack of unity), in a particular theoretical principle, in political doxa, in the critic, or in the teacher. (p.12)

James Hirsch's approach to teaching complex texts fully partakes of Martin's view. According to him, "if our class discussions generated simple and easy answers, we would falsify the complex and disturbing experience the play was evidently designed to produce" (2002, p.79). Although Hirsch is here referring to Webster's The White Devil, the conclusion he reaches about the best way to approach the play can be similarly applied to Lear's elusive complexity and ambiguity, a feature that has been repeatedly identified as a defining mark of Shakespeare's play.

As Derek Peat argues in his article “And That's True Too? King Lear and the Tension of Uncertainty”, the play forces us to "choose between the contrary possibilities it holds in unresolved opposition" (1980, p.43) [as qtd. in Kahan, 2008, p.88], or, in Terry Eagleton's words, "King Lear is a puzzle unlikely to be solved by any interpretative reading” (1986, p.83) [as qtd. in Kahan, 2008, p.86].

Aware that King Lear is a most suitable play to elicit the student's critical thinking, it is now time to outline a teaching framework which may cover those relevant aspects of the play which Manfred Pfister describes as "the various levels of verbal and non-verbal communication, of plot and 'character', of time and space". As he makes clear, emphasis must be placed on "how those levels interrelate", and "how those internal structures of dramatic texts function within the wider contexts of the theatre as a historically changing institution, of authorial intentions and audience expectations, and of social conditions and ideological frames" (1993, p.295).

These features roughly correspond to Rob Pope's model for analysing dramatic texts, which consists of "products, (re)producers, receivers and relations to the rest of the world" (1998, pp.68-76). The last heading ("relations to the rest of the world") is closely related to what most critics define as historical context. Its increasing attention on the part of teaching practitioners was celebrated by Ann Thompson in her "King Lear and the Politics of Teaching Shakespeare", where she highlighted the increasing importance awarded by critics to "the specificity of the historical, social, political circumstances surrounding both the original production of texts and their reproduction in our culture" (1990, p.141).

Critics such as Christiana Luckyj comment on the usefulness of taking historical documents to class as a means of modifying the students" "oversimple view of early modern culture" and "expose them to a range of cultural material that illuminates just how multiple and unstable those codes could be" (2002, p.141).

A. R. Braunmuller, however, asks for an honest employment of contemporary letters and documents because, he argues, "just as it is important for students to sense the past's reality, so too they need to recognize our fallible means of knowing the past" (2002, p.42).

Taking into account Braunmuller's judicious remarks, it is interesting to recall Hunter's synthesis of the double function that historical knowledge should fulfil for students, since, as he argues, it should not only help them "dispel their feeling of unfamiliarity" with the past, but, at the same time, it should lead them to "explore unfamiliarity", so 
as to assess "whether facts have been assumed or challenged in the literary discourse" (2002, p.167). It is by approaching texts in this light that they can develop that "understanding of otherness" that Burwitz-Melzer claims as an essential feature of literary studies (2001, p.29).

\section{How to Approach King Lear: Practical Suggestions}

Our selection of texts, historical documents and filmed versions of King Lear are intended as a means to help students achieve that familiarity with the different historical and socio-political contexts of production and reception that, at the same time, may enable them to realize where different "(re)producers" (Pope, 1998) have challenged familiar conceptions of state, family relationships, order, truth, or obedience.

A number of key passages are analyzed in their written form and in relation to different stage performances and film versions.

\subsection{Making Students Aware of Textual Difference: Dramatic Irony and Character Construction in $F$ and $Q$}

The students' attention is drawn to the complex textual situation which accompanies most of Shakespeare's plays, whose original manuscripts are no longer available. (Note 2) In the case of King Lear, they are made aware of different editorial practices, ranging from those synoptic editions where editorial choices are made silent to those editions which offer complete texts of the most outstanding Quarto and Folio versions of the play. Taking into account the considerable textual complexity of King Lear, a relevant selection of variants is chosen for the students to realize how significant textual differences can amount to be for aspects as important as character construction or dramatic irony.

Students are invited to compare the effect upon the play of the inclusion of some lines that are only present in the Folio version of the play. Thus, Lear's reasons for dividing his kingdom among his daughters are rendered differently in both versions. Although both F and Q offer the following beginning of Lear's address to his daughters:

Know that we have divided

In three our kingdom; and 'tis our fast intent

To shake all cares and business from our age,

Conferring them on younger strengths. (I.i. 36-39)

only the $\mathrm{F}$ version gives the following explanation:

while we

Unburdened crawl toward death (I.i.39-40) [My italics]

which anticipates the ironic ending of the play, with the old king entering "with Cordelia in his arms" and saying: "she's gone for ever" (V.iii.257).

As the students come to realize at this point of the play, Cordelia's death has been the outcome of the civil war which ensued from Lear's division of his kingdom among his daughters. The F version, again, stresses this dramatic irony in the words it assigns to Lear in the opening speech:

Our son of Cornwall,

And you, our no less loving son of Albany,

We have this hour a constant will to publish

Our daughters' several dowers, that future strife

May be prevented now. (I.i. 39-44) [My italics]

The $\mathrm{F}$ version of the first scene also contains significant variants which affect character construction. The most significant addition is probably Cordelia's emphatic refusal to pronounce the loving words which his father expects from her. Thus, whereas $Q$ gives us the following dialogue between royal father and daughter:

[LEAR] What can you say to draw

A third more opulent than your sisters?

[CORDELIA] Nothing, my lord.

F significantly changes it to

[LEAR] What can you say to draw

A third more opulent than your sisters? Speak. 
[CORDELIA] Nothing, my lord.

\section{[LEAR] Nothing?}

[CORDELIA] Nothing.

which emphasizes Lear's surprise as well as Cordelia's stubbornness and determination to uncover her sisters' "glib and oily art / To speak and purpose not" (I.i.226), an art she is proud to lack, since, as she makes clear, "what I well intend, / I'll do't before I speak" (I.i.227-228).

\subsection{Understanding Shakespeare's Creative Appropriation of His Sources}

The creative transformation which Shakespeare has effected on the various sources he has drawn on is similarly highlighted by presenting the students with excerpts from previous texts which could have inspired Shakespeare's rewriting. The students' attention is drawn towards Shakespeare's rhetorical powers when presented with two different versions of the speeches which are central to the opening scene of the play. Thus, Cordelia's words in Holinshed's History of England (1587) are compared to Cordelia's reply to her father in King Lear. The words assigned by Holinshed to Cordelia:

I love you as my naturall father $[\ldots]$

so much as you are worth,

And so much I love you, and no more (226)

can be easily recognized in Cordelia's reply to her father:

I love you according to my bond, no more, no less. (I.i.93)

The difference, however, lies in the elaboration that follows Cordelia's statement, which turns her into a fully articulate character intent on unmasking the true nature of her sisters' boundless love:

Good my lord,

You have begot me, bred me, loved me. I

Return those duties back as are right fit,

Obey you, love you and most honour you.

Why have my sisters husbands, if they say

They love you all? Haply when I shall wed,

That lord whose hand must take my plight shall carry

Half my love with him, half my care and duty.

Sure I shall never marry like my sisters

To love my father all. (I.i.95-104)

The fact that Cordelia is still unmarried and that her two suitors are still expecting an answer may have affected her decision to choose a line of argument that may be reassuring for her future husband.

\subsection{Understanding Theatrical Adaptation: Nahum Tate's 1681 version of King Lear and the Carolean Context}

Students are also made aware of the open nature of texts, as well as their close dependence on their socio-political context, by comparing the final scene of King Lear with the ending of the most long-standing version of the play: Nahum Tate's 1681 adaptation of King Lear, which successfully held the stage for over 150 years. Its emphasis on the Restoration of monarchy, and especially, on Cordelia's happy accession to the throne can only be fully grasped when recalling the Exclusion Crisis, which reached high point the same year Tate's version of the play was premièred. A fuller understanding of the close interdependence between literary arts and politics can be gained when presented with an excerpt from John Dryden's Absalom and Achitophel, also published in 1681, where the Exclusion Crisis is allegorically handled in biblical terms (Note 3).

Students are asked to compare Albany's description of the kingdom at the end of King Lear:

[ALBANY] Our present business

Is to general woe. [To Edgar and Kent] Friends of my soul, you twain,

Rule in this realm and the gored state sustain (V.iii.317-319) [My italics]

which is echoed by Edgar's: 
The weight of this sad time we must obey (V.iii.322)

with Lear's joyous celebration of his daughter's accession to the throne in Tate's version:

[LEAR] Cordelia then shall be a Queen, mark that:

Cordelia shall be Queen. Winds catch the sound

And bear it on your rosie wings to Heaven.

Cordelia is a Queen.

and Edgar's final description of the blooming kingdom:

[EDGAR] Our drooping country now erects her head,

Peace spreads her balmy wings, and plenty blooms.

\subsection{Understanding the Political Context: King Lear in the Light of Contemporary Documents}

The varying political circumstances under which the different versions of Lear have been staged is further illuminated by means of historical documents which are offered for students to comment on. A letter sent by King James I to the House of Commons on 1 May 1604 is analysed in relation to the central topic of the division of the kingdom. Discussion is centred on the passage where he tells the Commons that they are "contemning God's benefits, so freely offered unto us [...] by preferring war to peace, trouble to quietness, hatred to love, weakness to greatness, and division to union", since their refusal of his proposal would "sow the seeds of discord to all our posterities" (as qtd. in Brown, 2009, p.106).

Students are similarly presented with an excerpt from James I's Basilikon Doron (The King's Gift) addressed to his eldest son, Prince Henry, in 1603, in which he strongly advises his future heir to keep the unity of his kingdom, should he ascend the throne. Although Prince Henry met an untimely death in 1612 and never had the chance of following his father's advice, the King's words clearly illustrate his views on the central topic of Shakespeare's tragedy. He says:

And in case it please God to prouide you to all these three kingdomes, make your eldest son Isaac, leauing him all your kingdomes; and prouide the rest with priuate possessions: Other wayes by deuiding your kingdomes, yee shall leave the seed of diuision and discord among your posteritie. (as qtd. in Foakes, 2004, p.15)

The King's emphasis on the importance of unity brings forth the issue of the freedom allowed to Shakespeare and the Company of the King's Men to perform a play before the absolutist James I in which a king lost complete power and even human dignity. The question is then raised as to the possibility of reading the text in didactic terms, in so far as civil war is the consequence of the unwise division of a kingdom.

\subsection{Grasping the Instability of Cultural Codes}

At the private level of family relationships, a letter sent by Princess Elizabeth to her father, King James I, in April 1613 , similarly casts light on the need to read texts from the past bearing in mind the specific ideological context of its moment of production. Read in this light, Regan's protestation of absolute love for her father, which could sound as merely hypocritical flattery and exaggerated proof of submission, seems less so when contrasted with Elizabeth's similar declarations of love for her royal father, in spite of her recent marriage to Prince Frederick of Bohemia. Regan's:

I profess

Myself an enemy to all other joys

Which the most precious square of sense possesses,

And find I am alone felicitate

In your dear highness' love (I.i.72-76)

bears a close resemblance to Elizabeth's similar declaration of love for her father:

My heart, which was pressed and astounded at my departure, now permits my eyes to weep their privation of the sight of the most precious object, which they could have beheld in this world [...] [I wish I could] show your majesty with what ardent affection I am and will be, even to death, your majesty's very affectionate, very humble, and very obedient daughter and servant. (as qtd. in Foakes, 2004, p.38) (Note 4)

The previous quotation may, in turn, help students read in a new way Cordelia's refusal to pronounce a ceremonial type of discourse, especially when taking into account that it is followed by a detailed exposition of the impossibility for a married woman to devote complete love to her father. Taking this document into account, a ceremonial 
discourse addressed by a daughter to her royal father does not seem as hyperbolical as it could initially sound, if judged from a twenty-first century perspective. At the same time, Cordelia's refusal to answer an explicit request on her father's part to speak in such a rhetorical key is a clear sign of rebelliousness, especially when she exhibits complete mastery of the size and division which Lear had explicitly marked in his opening address:

[LEAR] Which of you shall we say doth love us most,

That we our largest bounty may extend

Where nature doth with merit challenge? (I.i.51-53)

Even though Cordelia says that she "cannot heave / her heart into her mouth", she bluntly replies: "I love your majesty / According to my bond, no more nor less" (I.i.92-93).

\subsection{Approaching King Lear in Film}

Students are constantly reminded of the theatrical nature of King Lear and are made aware of the multiplicity of sign-systems that interrelate in a performed or filmed version of the play. Taking advantage of the availability of different film and television versions of King Lear, they are shown the first scene from three different adaptations: Peter Brook's 1970 film, starring Paul Scofield; Jonathan Miller's 1982 version for the BBC TV, with Michael Hordern cast as Lear; and the 1983 version directed by Michael Elliott for Granada Television, with Laurence Olivier in the leading role.

The students are asked to concentrate on aspects as significant as text cutting, delivery of lines, gestures, rhythm, spatial distribution of characters on stage, setting, costumes, use of props, music and camera movement. Lively discussion follows as to the consequences of each choice on the overall effect of the scene, and, ultimately, on the play. (Note 5)

\section{Conclusion}

The type of approach to teaching King Lear which has been described in the previous pages proves a fruitful and enjoyable experience for students, and helps them look at classical texts and their contemporary rewritings with a critical eye. As a result of the different tasks they engage in, their linguistic, historical, theatrical and intercultural skills are enhanced to such an extent that they acquire the competence which they need to approach other early modern texts in a confident manner.

\section{References}

Bamford, K., \& Leggatt, A. (2002). Approaches to teaching English renaissance drama. New York: The Modern Language Association of America.

Braunmuller, A. R. (2002). Performance conditions. In K. Bamford, \& A. Leggatt (Eds.). pp. 35-43

Brown, J. R. (2009). King Lear. The Shakespeare Handbooks. Houndmills: Palgrave Macmillan.

Burwitz-Melzer, E. (2001). Teaching intercultural communicative competence through literature. In M. Byram, A. Nichols, \& D. Stevens (Eds.). Developing intercultural competence in practice. New York: Multilingual Matters. pp. 29-44

Byram, M., Nichols, A., \& Stevens, D. (Eds.). (2001). Developing intercultural competence in practice. New York: Multilingual Matters.

Candido, J. (2002). Teaching texture in Jonson's. In K. Bamford, \& A. Leggatt (Eds.). The alchemist. pp. 51-59

Durant, A., \& Fabb, N. (1992). Literary studies in action. London: Routledge.

Eagleton, T. (1986). William Shakespeare. Oxford: Basil Blackwell.

Griggs, Y. (2009). Peter Brook's King Lear (1971): “A Hollywood showman's nightmare”. In Y. Griggs. Screen adaptations. Shakespeare's King Lear. London: Methuen. pp. 41-62

Hirsch, J. (2002). Vittoria's secret: Teaching Webster's. In K. Bamford, \& A. Leggatt (Eds.). The white devil as a tragedy of inscrutability. pp. 73-80

Holinshed, R. (1927). Holinshed's chronicle as used in Shakespeare's plays. In A. Nicoll, \& J. Nicoll (Eds.). London: J. M. Dent and Sons.

Hunter, J. (2002). How much history is enough? In K. Bamford, \& A. Leggatt (Eds.). Overcoming the alienation of early modern drama. pp. 165-172

Kahan, J. (Ed.). (2008). King Lear. New critical essays. Shakespeare Criticism Vol. 33. London: Routledge. 
Leggatt, A. (2002). Classroom practice. In K. Bamford, \& A. Leggatt (Eds.). pp. 3-6

Leggatt, A. (2004). King Lear. Shakespeare in performance. (2nd ed.). Manchester: Manchester University Press.

Luckyj, C. (2002). Historicizing gender: Mapping cultural space in Webster's. In K. Bamford, \& A. Leggatt (Eds.). The duchess of Malfi and Cary's The tragedy of Mariam. pp. 134-142

Martin, B. (1997). Teaching Literature, Changing Cultures. Publicatons of the Modern Language Association of America, January, 7-25

McGee, C. E. (1980). Webbing Webster. In K. Bamford, \& A. Leggatt (Eds.). pp. 105-113

Peat, D. (1980). "And That's True Too": King Lear and the Tension of Uncertainty. Shakespeare Survey, 33, 43-53. http://dx.doi.org/10.1017/CCOL052123249X.005

Pfister, M. (1993). The theory and analysis of drama. Cambridge: Cambridge University Press.

Pope, R. (1998). The English studies book. London: Routledge.

Rosenberg, M. (1972). The masks of King Lear. Berkeley/Los Angeles: University of California Press.

Shakespeare, W. The complete works. Stanley Wells, S., \& Taylor, G. (Eds.). (1986). Oxford: Clarendon Press.

Shakespeare, W. Comedies, histories and tragedies. Published according to the true original copies. London: Printed by Isaac Iaggard, and Ed. Blunt, 1623. English Drama Online (1994). Cambridge: Chadwyck-Healey.

Shakespeare, W. King Lear: A parallel text edition. Weis, R. (Ed.). (1998). London: Longman.

Shakespeare, W. King Lear. Foakes, R. A. (Ed.). (2004). The Arden Shakespeare. Third Series. Cambridge, Walton-on-Thames, Surrey: Thomson Learning and Sons Ltd.

Tate, N. The history of King Lear. Acted at the Duke's Theatre. Reviv'd with alterations. London: Printed for E. Flesher and are to be sold by R. Bentley, and M. Magnes in Russel-street near Covent-Garden, 1681. English Drama Online. (1994). Cambridge: Chadwyck-Healey.

Taylor, G., \& Warren, M. (Eds.). (1983). The division of the kingdoms: Shakespeare's two versions of King Lear. Oxford: Clarendon Press.

The true chronicle history of King Leir, and his three daughters, Gonorill, Ragan and Cordella. As it hath bene diuers and sundry times lately acted. London: Printed by Simon Stafford for Iohn Wright, 1605. English Drama Online (1994). Cambridge: Chadwyck-Healey.

Thompson, A. (1990). King Lear and the Politics of Teaching Shakespeare. Shakespeare Quarterly, 41 (2), 139-146. http://dx.doi.org/10.2307/2870444

\section{Notes}

Note 1. See Durant and Fabb (1992, p. 48) for a similar approach.

Note 2. Students can find a detailed account of textual issues concerning King Lear in Taylor and Warren (1983).

Note 3. Dryden's Absalom stands for Charles II's illegitimate son, the Duke of Monmouth, whereas Achitophel corresponds to Shaftesbury, who tried to prevent Charles II's legitimate successor -the Duke of York and future King James II- from ascending the throne. Shaftesbury's ultimate aim in attempting to impose on the king an illegitimate heir as his successor was to increase the power of Parliament.

Note 4. Letter printed by Mary Anne Everett Green in Elizabeth, Queen of Bohemia, revised by S. C. Lomas (1990, p. 64), qtd. in Rosenberg (1972, p. 51).

Note 5. At a later stage, students are invited to compare their conclusions regarding these aspects of performance with Kahan's brief remarks on them (2009, pp. 70-71, 74-77), as well as with Leggatt's insightful analysis of these versions in "Peter Brook" (2004, pp. 105-118), "Jonathan Miller and Michael Hordern" (2004, pp. 118-132) and "Laurence Olivier" (2004, pp. 132-144). 